formally united with the Tropical Products Institute, which specializes in post-harvest storage, to form the Tropical Development and Research Institute. The new institute, which is still seeking a site, is planned to save $£ 475,000$ through a "greater concentration of effort" and staff reductions of 10 per cent. FAC says the merger was not warranted by the Rayner scrutinies, which took "no serious account" of the value of training and scientific information the units provide. It says funds for the two units were well spent and that resources for both should be increased. The merger is widely unpopular with staff of the new institute.

Of the other two units, the Directorate of Overseas Surveys, which produces specialist maps and surveys, will cease to exist in its present form and will be merged with the Ordnance Survey. The government's scrutiny by the Rayner Unit found the directorate to be inclined to an "overartistic" approach to cartography but recognized it as a centre of excellence. The move to Ordnance Survey's headquarters at Southampton will involve staff reductions of 60 per cent, and many cartographers have already resigned. FAC concludes, after consultations with international aid organizations, that the need for surveying and mapping in developing countries is increasing and doubts whether the directorate will be able to sustain its "highly regarded" work if the planned changes are made.

The Land Resources Development Centre (formally a "special" rather than a "scientific" unit) is to have its staff complement cut to 45 , from a 1979 figure of 83. FAC says that the reduction will decrease the centre's cost-effectiveness, which it says compares well with the private sector. The centre is concerned with applied land-use research and undertakes training in developing countries.

The government's plans for the four units, which account for 1 per cent of the overall aid budget, are described by FAC as "a short-sighted error for the sake of small and short-term savings"; the damage to the units, which have an "extremely high international reputation", will "probably be irreversible".

FAC endorses the government's aims of increasing efficiency and encouraging the units to act in a more entrepreneurial manner; this would, it says, increase flexibility as well as efficiency. The aims are consistent with the general enthusiasm in government for "privatization" and the Rothschild customer/contractor principle. But FAC says the units must have more reliable central funding and should be permitted to seek additional funds from outside sources if their accumulated expertise is to be protected. It is not known how the government will respond to the FAC report; however, one senior ODA official, asked what impact the report may have, said "Almost certainly none at all".

Tim Beardsley

Soviet oceanography

\title{
Costly neglect of plate tectonics
}

SOVIET neglect of plate tectonics could have serious economic consequences, two leading Soviet oceanologists warned recently. In a major article in Pravda, Dr Andrei Monin, director of the Institute of Oceanology of the Soviet Academy of Sciences and Dr Leonid Brekhovskikh, secretary of the Academy's Department of Oceanology, Atmosphere Physics and Geography, accused the Ministry of Geology of making insufficient use of recent advances in tectonics. Moreover, they said, the Ministry of Higher and Specialized Secondary Education needed to update university courses in geology, which dealt only superficially with tectonics.

By the time the article had appeared in Pravda, Dr Brekhovskikh was aboard the research ship Academik Mstyslav Keldysh, leading a major expedition with an acoustic monitoring programme aimed at developing rapid acoustic methods for the location of iron and manganese nodules on the seabed. So far, sea-bed exploration has been left almost entirely to the initiative of the Academy of Science's "Commission on Problems of the World Ocean" - which coordinates the efforts of the Institute of Oceanology, the four earth-sciences institutes, and also the Far Eastern Centre of the Soviet Academy and the Institute of Geological Sciences of the Ukrainian Academy. But the main initiative in undersea exploration has come from the oceanologists - largely due to the reluctance of certain leading geologists, notably $\mathrm{Dr}$ Vladimir Belousov, to accept the theory of plate tectonics. This divergence of opinion was carefully glossed over by Monin and Brekhovskikh with a call for "greater creative cooperation" between oceanologists and geologists, and an allusion to the work done by Soviet oceanologists in the development of plate tectonics.

During the past decade, Soviet oceanologists have, indeed, made a number of notable advances, including the 1976 expedition of the Dmitrii Mendeleev, which yielded unique rock specimens from layers 2 and 3 of the oceanic crust, the magnetic survey of the Baltic by the vessel Zarya in 1981 and the tectonic mapping of ore occurrence and recovery of iron-manganese nodules in the neighbourhood of the Owen fracture by the Akademik Vernadskii in 1979. Very little such work, however, has been organized from the geologists' side one notable exception being the Bellinghausen and Gidrolog expedition of 1979 , which was a joint venture of the Institute of Geology of the Ukrainian SSR and the naval hydrographic service.

The use of submersible manned and remote-controlled craft has played a major role in these ventures. These are generally multipurpose vehicles, which combine the recovery of bed samples with the photography and video-recording of marine life. They include the Argus, which can operate at depths of $600 \mathrm{~m}$ and glides over the bottom on ski-supports, and the Pisces, which can operate to depths of $2,000 \mathrm{~m}$, the Manty and $K r a b$, which are equipped with special manipulators, and the Okeanolog, which has electrohydraulic grabs capable of removing up to $20 \mathrm{~kg}$ of bed samples at a time, and fitted with special engines enabling it to "hover". However, although the Soviet Union can boast of more than 120 research ships (not counting almost the same number of specialized vessels of the hydrometeorological and fisheries services) it has fallen badly behind as regards research submersibles. In all, say Monin and Brekhovskikh, there are some 200 such craft in the world - but only "twentyplus" of these belong to the Soviet Union. The "further development of earth sciences and the needs of [Soviet] industry" they conclude, requires the considerable expansion of the submersible "fleet" in the nearest future. Vera Rich

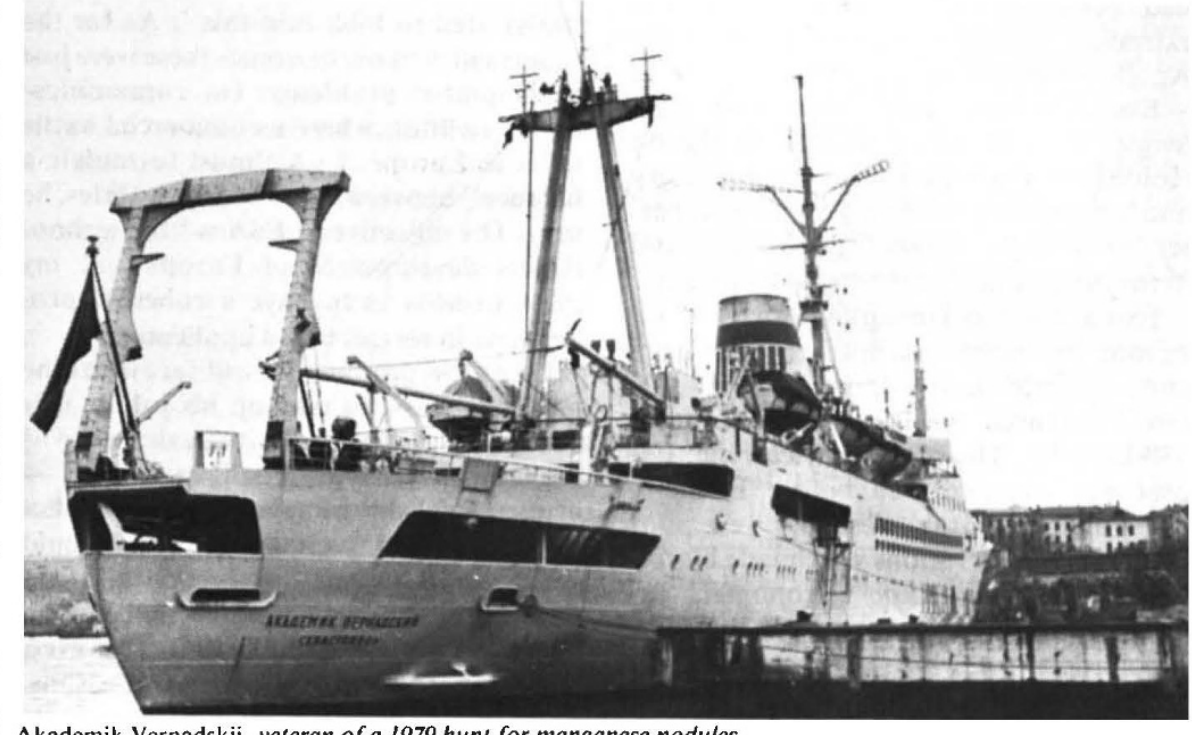

Akademik Vernadskii, veteran of a 1979 hunı for manganese nodules 